\title{
Is Standard Costing Still Used? Evidence from Turkish Automotive Industry
}

\author{
A. Cemkut Badem ${ }^{1}$, Emre Ergin $^{2} \&$ Colin Drury ${ }^{3}$ \\ ${ }^{1}$ Accounting and Finance Department, Faculty of Economics and Business Administration Science, Kocaeli \\ University, Kocaeli, Turkey \\ ${ }^{2}$ Accounting and Tax Department, Izmit Vocational School, Kocaeli University, Kocaeli, Turkey \\ ${ }^{3}$ Department of Accountancy, University of Huddersfield, UK \\ Correspondence: Emre Ergin, Accounting and Tax Department, Izmit Vocational School, Kocaeli University, \\ Turkey. Tel: 90-262-351-328-7216. E-mail: emre.ergin@kocaeli.edu.tr
}

Received: May 9, 2013

Accepted: June 4, $2013 \quad$ Online Published: June 14, 2013

doi:10.5539/ibr.v6n7p79

URL: http://dx.doi.org/10.5539/ibr.v6n7p79

\begin{abstract}
Today, there is a debate about the future of standard costing. Some academicians assert that this method is inappropriate in a modern manufacturing environment. The aim of this article is to study the use of standard costing in the automotive industry, the leading manufacturing sector of Turkey. The findings show an average usage rate of 77 percent for standard costing. The majority of non-users are local small supplier firms. There are statistically significant differences between the primary and supplier industries in terms of its importance and usage. Just to name a few differences, supplier firms attach less importance to the budgetary function of the standard costing, and they mostly rely on different methods to set labour and material standards.
\end{abstract}

Keywords: cost control, standard costing, management accounting, automotive industry

\section{Introduction}

Technological developments and globalization increase competition that firms face in order to survive. Manufacturing costs are one of the main tools that firms have still some control to compete in the market. Today, there is a debate about the usefulness of standard costing in today's manufacturing environment (Drury, 1999; Hilton, 2001; Joshi, 2001; Kaygusuz, 2006a). The justification of this claim is that standard costing does not meet the needs of business because of the introduction of advanced manufacturing technologies (AMT, JIT, TQC), shorter product life cycles, decreasing emphasis of labour cost in the total production costs, and intense global competition. However, the literature suggests that standard costing continues to be used. The aim of this article is to investigate whether the standard costing is still widely used in the automotive industry which has the biggest export sector in Turkey.

The automotive industry is currently among the three largest manufacturing industries in Turkey. The automotive industry includes primary and supplier firms. There are 13 primary firms, which produce by assemblage. The supplier firms consist of many small and medium-sized enterprises (SMEs) which specialized in the production of similar products.

The Turkish automotive industry has a history of 50 years. In the 1950 s, the country began manufacturing cars only with assembly lines. During the 1980s, the Turkish automotive industry was based on the import substitute model. After 1996, as a result of the work carried on for the integration with the European Customs Union, the sector was transformed into one that produces high quality products, for export to global markets. During this period, Turkey became one of the car manufacturing bases for the major international automotive companies. In the automotive industry, which is literally a global sector, car manufacturers have plants abroad other than their domestic production units. This applies to Turkey where transnational firms established their plants many years ago. The domestic and foreign investments followed by the European Customs Union were important milestones of the industry to reach the current levels (Automotive Manufacturers Association, 2011, p.7).

Nowadays, the Turkish primary and supplier automotive industries are the largest light commercial vehicle (LCV), and the second largest autobus manufacturers in Europe (Republic of Turkey Ministry of Economy RTME, 2012). According to the 2011 data, Turkey ranks 17th among 45 countries with 639.734 cars and 549.397 
commercial vehicles produced (Organisation Internationale des Constructeursd' Automobiles, 2011).

Automotive primary and supplier industries accounted for 15,8\% and 15,6\% of the total exports of the country in 2010 and 2011 respectively. In 2011, the export figures were USD11.9 and USD8.2 billion respectively for the primary and supplier industries. In 2011, the automotive industry was ranked the first in terms of exports. The primary and supplier automotive industries have a share of 5\% in the total manufacturing industry. It is estimated that of 400.000 people 47.000 of them work in the primary automotive industry, and 203.000 of them in the supplier automotive industry. It is also estimated that the rest are employed in the distribution, marketing and sales in the Turkish automotive industry (RTME, 2012).

Today, primary firms produce passenger vehicles, autobuses, trucks, pickups, minibuses, and midibuses. The total capacity of those firms consists of 1,5 million units per year. These firms work directly with the 1.120 automotive supplier firms that operate in Turkey. There are 4.000 automotive supplier firms of which 200 are foreign (RTME, 2012).

There are five primary firms that produce passenger vehicles: Renault, Tofaş (Fiat), Toyota, Hyundai, and Honda. Ten firms (Anadolu Isuzu, BMC, Ford Otosan, Hyundai, Karsan, M.A.N., Mercedes-Benz, Otokar, and Temsa) manufacture trucks and pickups. Nine firms (Anadolu Isuzu, BMC, Karsan, Mercedes-Benz, Hyundai, Otokar, Ford Otosan, Temsa, and M.A.N.) are involved in the production of autobuses and minibuses (RTME, 2012). This study did not included Askam (Chrysler) that manufactures trucks, as it was not included in the RTME report.

The literature search indicated that there was no previous research on standard costing for planning, control, and decision making processes for the Turkish manufacturing sector. This is the first study conducted for the automotive industry, which is one of the leading industries in Turkey. The first reason why the automotive sector was chosen was because it has the highest level of exports. Secondly, the automotive industry is assumed to be an industry where standard costing has traditionally been used. Thus, it is interesting to study this sector to check whether the firms still rely on standard costing. Thirdly, since the primary and supplier industries are located in Kocaeli, Sakarya and Bursa, the geographical proximity enabled the questionnaires to be easily collected, and also conduct face-to-face interviews. The study also investigates whether there are differences in the usage of standard costing in relation to primary and supplier firms.

The following part in the paper is a literature review. The third part focuses on the research method; in the fourth part the results are presented and interpreted. The fifth and last part summarizes the results and considers suggestions for the future research.

\section{Literature}

This section defines the objectives of standard costing, and reviews the literature.

\subsection{The Objectives of Standard Costing}

The main reason for the emergence of standard costing is that relying only on actual costs could not appropriate data on managerial activities which are needed by managers. As a general statement, standard costing aims to provide the cost information relating to controlling costs, providing convenience and quickness to compute production costs, preparing business budgets, pricing products, and measuring the performance of division managers (Küçüksavaş, 2006, p.500).

Standard costing is especially used in production industries where the same products are permanently produced. Petroleum refinery, pharmaceuticals and chemistry industries, automotive, canned vegetable and fruit, and fast food restaurant industries can be given as examples (Williamson, 1996, p.519). In addition to these industries, standard costing is also used in many service industries, and nonprofit organizations (Hilton, 2001). For instance, in the auto services, workers' time standards are applied to specific repair and maintenance services; in the hospital services, food, laundry, laboratory usages are standardized for daily accommodation (Garrison, 1998, p.383); in the air transportation, fuel and repair costs are standardized (Hilton, 2001, p.410).

\subsection{Scientific Studies in Literature}

Some academicians suggest that standard costing is no longer suitable in today's highly global and competitive world, and have suggested that firms abandon this method (Kaplan \& Johnson, 1987; Monden \& Lee, 1993; Ferrara, 1995; Lucas, 1997; Fleischman \& Tyson, 1998; Hilton, 2001; Gupta \& Gunasekaran, 2004). Drury (2009) stated that the usefulness of standard costing in a modern business environment has been questioned because of the changing cost structure, inconsistency with modern management approaches, over-emphasizes the importance of direct labour, and delay in feedback reporting. Other studies suggest that standard costing is 
widely used in many parts of the world in different industries (Joshi, 2001; Garg et al., 2003; Sulaiman et al., 2005; Dugdale et al., 2006; Marie et al., 2010).

Standard costing has been widely used in developed countries. Although the main purpose is to control costs, standard costing has also contributed to managerial activities such as budgeting and product pricing (Büyükmirza, 2003, p.606). For instance, surveys that were performed during the 1980s and 1990s showed that production firms mostly used standard costing systems. The reported usage rates were $65 \%$ in Japan, $73 \%$ in Sweden, 76\% in England, 84\% in Ireland, and 86\% in USA (Horngren et al., 1997, p. 225).

Many academicians documented that most of the large firms used standard costing for decision taking, cost control, and performance evaluation (Cornick et al., 1985; Ghosh et al., 1987; Lyall \& Graham, 1993; Joshi, 2001). Studies that compared developing and developed countries reported that firms in both of those countries widely used standard costing (Puxty \& Lyall, 1990; Bromwich \& Wang, 1991; Tho et al., 1998; Joshi, 2001).

Studies conducted in developed countries have reported usage rates of $73 \%$ in the U.K., and $86 \%$ in Japan (Garg et al., 2003). Lyall and Graham (1993) asserted that more than 90\% of 231 firms surveyed in the U.K. apply standard costing for cost control purposes. $63 \%$ of the managers using this method affirmed they were satisfied by its decision-making support. Guilding, Lamminmaki, and Drury (1998) documented that standard costing is used by $76 \%$ of 303 accountants in the U.K. and $73 \%$ of 85 finance and accounting specialists in New Zealand. A survey performed in India showed that $68 \%$ of the 60 firms used standard costing (Joshi, 2001). A survey made in Singapore revealed that the method was used by $47 \%$, and another survey performed one decade later showed that the usage ratio had increased to 56\% (Ghosh \& Chan, 1996). Murshed (1997) showed that international companies in Brunei frequently employ variance analysis as well as standard costing. Other studies have found similar results in other countries such as Japan (Scarborough et al., 1991), Taiwan (Tsai, 1995), Philippines (Diga, 1997), and Korea (Ahn \& Lee, 1994).

The study by Sulaiman, Ahmad, and Alwi (2005) found widespread continuance of standard costing: $70 \%$ of Malaysian and $76 \%$ of Japanese companies. Marie, Cheffi, Louis, and Rao (2010) found that $77 \%$ of industrial firms operating in Dubai used standard costing in order to control cost, evaluate performance, calculate production cost, and budget.

Although the above findings support the usage of standard costing, some writers question the usage of standard costing on the basis that this method is no longer relevant for today's production methods, and it should not be used or should be used after some revisions.

Standard costing is criticized especially in an advanced production environment that results in declining direct labour and material costs, reduced inventories and just-in-time production methods (Kaygusuz, 2006b, pp.64-65). The criticisms increased especially during the second half of the 1980s. Some academicians affirm that the importance of standard costing and variance analysis for cost control and performance evaluation decreased due to the fierce competitive environment (Kaplan \& Johnson, 1987; Monden \& Lee, 1993; Ferrara, 1995). Fleischman and Tyson (1998) affirm that the method is inefficient to detect the necessary strategic signals. Other researchers point to the meaningless benefits of the method in respect to highly sophisticated production cycles (Lucas, 1997; Hansen \& Mowen, 2002). In general, the criticisms of standard costing mainly relate to today's high competitive environment and improving production technologies. The decreasing role of labour and shortened product life cycles caused large firms to plan their activities with different production philosophies such as Product Life Cycle Management, Just-in-Time manufacturing, Activity Based Management (ABC), and Total Quality Management. The firms use strategic cost methods - namely ABC, Target Costing, Product Life Cycle Costing for the calculation of production costs and their control. These developments decreased the importance of standard costing (Hilton, 2001; Gupta \& Gunasekaran, 2004). The most severe criticism came from Lucas (1997) who stated that the method has become obsolete, and it should not be included in cost accounting courses. However, standard costing continues to be incorporated in cost and management accounting textbooks and university course curriculum.

\section{Research, Methodology, and Findings}

\subsection{Sample}

Three survey methods were used in order to obtain the data - electronic questionnaires, telephone and face-to face interviews (Note 1). The questionnaire was sent to all of the thirteen primary and 300 supplier companies in the automotive industry in Turkey. The questionnaire was sent to the accounting department of the firms. Either the accounting manager or the person responsible for the cost accounting was asked to complete the questionnaire. Out of the thirteen primary firms, responses were obtained from the 12 firms by one of the methods mentioned above. 
It was noted that all the primary firms use standard costing. Data was obtained from 78 supplier companies representing a response rate of 26 percent. Among the 78 supplier firms, 55 of them reported that they use standard costing.

\subsection{Questionnaire}

The questionnaire used in the survey was adapted from Drury, Braund, and Osborne (1993). Other researchers (Sulaiman et al., 2005) also used this questionnaire thus making it possible to compare their results with ours. The questionnaire used in the survey consists of two parts. The first part contained demographic questions. The second part contained seven questions. The first question in the second part to which respondents replied "yes" or "no" is related to the use of the standard costing. Respondents are asked to list the benefits of standard costing in the second question. The third question focused on the standards of methods to set material and labour. The fourth question related to the degree of access to the standards. The fifth question focused on how often the standards are revised. The sixth question centered on finding out if a specific variance should be studied. The seventh and final question asked respondents to determine the relevance of a specific variance for cost control purposes. A five-point Likert scale was used in questions 2 to 7.

\section{Results}

\subsection{Demographics}

Table 1 shows the ownership structure of the respondents. The results point to a high foreign ownership in the automotive industry in Turkey.

Table 1. Ownership structure

\begin{tabular}{lllll}
\hline & $100 \%$ Turkish & Mixed & $100 \%$ Foreign & Total \\
\hline Primary Firms & 4 & 5 & 3 & 12 \\
Supplier Firms & 30 & 24 & 24 & 78 \\
\hline
\end{tabular}

Notes: $\mathrm{n}=90$. Responses were obtained from 12 out of 13 primary firms, and 78 supplier firms in the automotive industry in Turkey.

Table 2 presents the yearly sales figures of the respondents. All of the supplier firms have large turnovers.

Table 2. Sales turnover

\begin{tabular}{lll}
\hline & Primary Firms & Supplier Firms \\
\hline Less than TL 9,9 Million & 0 & 21 \\
Between TL 10 and 49,9 Million & 0 & 29 \\
Between TL 50 and 99,9 Million & 0 & 19 \\
More than TL 100 Million & 12 & 9 \\
Total & 12 & 78 \\
\hline
\end{tabular}

Description: All of the primary firms have large sales. Most of the supplier firms are typically small and medium sized enterprises. The Turkish Lira (TL) exchange rates as of December 31, 2012 to US \$, Euro, and UK £ are 1.78, 2.35, and 2.88 respectively.

Table 3 gives the number of employees of the respondents.

Table 3. Number of employees

\begin{tabular}{lll}
\hline & Primary Firms & Supplier Firms \\
\hline Below 10 & 0 & 4 \\
Between 10 and 30 & 0 & 17 \\
Between 31 and 100 & 0 & 19 \\
Between 101 and 500 & 4 & 28 \\
Above 501 & 8 & 10 \\
Total & 12 & 78 \\
\hline
\end{tabular}

Description: Eight of the responded primary firms have more than 500 employees, and the other four has employees between 101 and 500 persons. The supplier firms have an average of 135 employees.

\subsection{Use of Standard Costing}

Standard costing is used by all the primary companies and 71 per cent of suppliers (Table 4). The overall usage percentage is $\mathbf{7 4}$, and is consistent with the studies undertaken in the UK (Drury et al., 1993), New Zealand 
(Guilding et al., 1998), and Malaysia (Sulaiman et al., 2005). Primary and large supplier firms still use standard costing. Although standard costing can be seen as an old method, it continues to be a preferred method in the automotive industry in Turkey. In the following parts, different aspects concerning the usage of standard costing are investigated for both the primary and supplier companies.

Table 4. Extent standard costing used by firms

\begin{tabular}{llllll}
\hline & Turkey & & Malaysia & UK \\
\cline { 2 - 4 } & Primary Firms & Supplier Firms & Total & & \\
\hline Yes & 100 & 71 & 74 & 71 & 76 \\
No & 0 & 29 & 26 & 29 & 24 \\
Total & 100 & 100 & 100 & 100 & 100 \\
\hline
\end{tabular}

Description: $n=90$. Turkish respondents of which 12 are primary and 78 are supplier firms. The demographic analysis of the $29 \%$ of the supplier that do not use standard costing shows that differences in responses of primary and supplier firms are due to size and ownership structure rather than industry factors. $61 \%$ of the supplier that do not use the method have local ownership, $52 \%$ have sales less than 10 million, and $65 \%$ have employees less than 30 person. It can be concluded that majority of the non-users are local small firms.

\subsection{Importance of Standard Costing}

Table 5 shows that primary companies attach equal importance to the different purposes of standard costing. Supplier firms give less importance to budgeting and data processing purposes.

Table 5. The importance of standard costing

\begin{tabular}{|c|c|c|c|c|c|}
\hline & \multicolumn{3}{|l|}{ Turkey } & \multirow{2}{*}{$\begin{array}{l}\text { Malaysia } \\
(\%)\end{array}$} & \multirow{2}{*}{$\begin{array}{l}\text { UK } \\
(\%) \\
\end{array}$} \\
\hline & Primary Firms $(\%)$ & Supplier Firms (\%) & Total $(\%)$ & & \\
\hline Cost control and performance evaluation & 100 & 100 & 100 & 82 & 72 \\
\hline Costing inventories & 100 & 98 & 99 & 73 & 80 \\
\hline Computing product cost for decision making & 100 & 93 & 94 & 79 & 62 \\
\hline As an aid to budgeting & 100 & 82 & 85 & 72 & 69 \\
\hline Data processing economies & 83 & 65 & 69 & 61 & 43 \\
\hline
\end{tabular}

Description: $\mathrm{n}=67$. In the questionnaire 4 stands for above average importance, and 5 stands for vitally important. Respondents who marked the Likert scales 4 and 5 are represented by the corresponding percentages in the above and the rest of the tables.

Primary and supplier firms are analyzed by Mann-Whitney U (MWU) test for any significant differences (Table 6). The means are computed for all responses. The percentages show responses that were rated 4 and 5 . Therefore, means and percentages might change in respect to their rankings.

Table 6. The importance of standard costing (means)

\begin{tabular}{lllllll}
\hline & Turkey & & & & Malaysia & UK \\
\cline { 2 - 5 } & Primary Firms & M-W test & Supplier Firms & Total & & \\
\hline Cost control and performance evaluation & 4,33 & 4,40 & 4,39 & 4,12 & 4,02 \\
Costing inventories & 4,58 & 4,36 & 4,40 & 3,97 & 4,25 \\
Computing product cost for decision making & 4,50 & $*$ & 4,25 & 4,30 & 3,99 & 3,69 \\
As an aid to budgeting & 4,67 & 3,96 & 4,09 & 3,96 & 3,90 \\
Data processing economies & 4,08 & 3,45 & 3,57 & 3,59 & 3,11 \\
\hline
\end{tabular}

Notes: *Significant at 5 per cent. The means are calculated for all responses.

Primary and supplier firms differ significantly in "as an aid to budgeting" function. SMEs rely on budgeting functions less than primary firms. This may be due to several reasons. First, most of the primary companies have foreign capital so the foreign shareholders imply a budgeting process. Second, local supplier companies do not have the same need to prepare a budget in their organizations. It can be claimed that the main reason for this difference is that SMEs do not have the consciousness to use budget as a managerial control tool. This is because the locally owned suppliers do not have the budgeting habit. A significant proportion of supplier companies do not have to rely on formal planning and control systems. They can plan and control by direct observation and plans can be communicated easily amongst the staff. Another reason is the costs of setting and implementing a budget control mechanism would be larger than the benefits that would be obtained from it. It is also explained by the cost 
and benefit of the budget preparation process. The inadequate capital structure of the SMEs obliges them not to give importance to budgeting function. Thus, supplier firms give less importance to budgeting.

\subsection{Setting Labour and Material Standards}

The results of setting labour and material standards are presented in Tables 7 and 8. Primary firms having large capital and financial funds operate in a severe competitive environment that obliges them to produce high quality products. Therefore, primary firms seem to give more importance to design and engineering studies during the setting of the standards.

Table 7. Method used to set labour and material standards

\begin{tabular}{llllll}
\hline & Turkey & & Malaysia & UK \\
\cline { 2 - 5 } & Primary Firms (\%) & Supplier Firms (\%) & Total (\%) & (\%) & (\%) \\
\hline Standards based on design/engineering studies & 100 & 24 & 37 & 55 & 51 \\
Observations based on trial runs & 0 & 56 & 46 & 45 & 30 \\
Work study techniques & 83 & 40 & 48 & 26 & 42 \\
Average of historic usage & 17 & 64 & 55 & 58 & 44 \\
\hline
\end{tabular}

Note: $\mathrm{n}=67$.

There is a significant statistical difference for all the methods investigated except for work study techniques. When setting the labour and material standards, supplier firms seem to use less engineering studies than average of historic usage, observations based on trial runs, and work study techniques. Supplier firms are specialized in the production of a few products so that it is important that they follow historical average, and observations based on trial runs to calculate the current setting.

Table 8. Method used to set labour and material standards (means)

\begin{tabular}{lllllll}
\hline & Turkey & & & & Malaysia & UK \\
& Primary Firms & M-W test & Supplier Firms & Total & & \\
\hline Standards based on design/engineering studies & 4,75 & $* *$ & 2,35 & 2,78 & 3,62 & 3,22 \\
Observations based on trial runs & 1,50 & $* *$ & 3,27 & 2,96 & 3,24 & 2,83 \\
Work study techniques & 3,75 & & 3,00 & 3,13 & 2,83 & 3,04 \\
Average of historic usage & 2,33 & $* *$ & 3,45 & 3,25 & 3,66 & 2,99 \\
\hline
\end{tabular}

Notes: ** Significant at 1 per cent. The means are calculated for all responses.

\subsection{Type of Standards}

The results relating to the type of standards used are presented in Tables 9 and 10. Primary firms answered the question concerning the type of standards with the highest percentage of $58 \%$ for maximum efficiency standards. It seems to be rational when this answer is evaluated with the prior one. They use standards based on design/engineering studies that probably lead to theoretical achievable levels, which is maximum efficiency standards. On the other hand, supplier firms give the highest answer (65\%) for average past performance. When this answer is considered with the previous question, supplier firms set standards by work studies, observations based on trial runs, average of historic usage, and it seems a natural outcome that they employ average past performance standards. Most of the supplier firms are specialized in the production of one specific product or a few intermediate goods (for instance, steering wheel, seat, seatbelt). This may explain that supplier firms, which are specialized in the production, prefer to reach achievable but difficult to attain standards.

Table 9. Types of standards employed by firm's standard costing system

\begin{tabular}{|c|c|c|c|c|c|}
\hline & \multicolumn{3}{|l|}{ Turkey } & \multirow{2}{*}{$\begin{array}{l}\text { Malaysia } \\
(\%)\end{array}$} & \multirow{2}{*}{$\begin{array}{l}\text { UK } \\
(\%) \\
\end{array}$} \\
\hline & Primary Firms (\%) & Supplier Firms (\%) & Total $(\%)$ & & \\
\hline Maximum efficiency standards & 58 & 16 & 24 & 21 & 5 \\
\hline Achievable but difficult to attain standards & 33 & 18 & 21 & 29 & 44 \\
\hline Average past performance standards & 8 & 65 & 55 & 38 & 46 \\
\hline Others & 0 & 0 & 0 & 13 & 5 \\
\hline Total & 100 & 100 & 100 & 100 & 100 \\
\hline
\end{tabular}

Note: $\mathrm{n}=67$. 
According to Table 10, the MWU test revealed that primary firms use 'maximum efficiency standards' to a greater degree compared with supplier firms. On the other hand, the test points out that the supplier firms rely on "average past performance standards" to a greater degree than primary firms.

Table 10. Types of standards employed by firm's standard costing system (means)

\begin{tabular}{lllll}
\hline & Turkey & & & \\
& Primary Firms & M-W test & Supplier Firms & Total \\
\hline Maximum efficiency standards & 3,08 & $* *$ & 2,00 & 2,19 \\
Achievable but difficult to attain standards & 2,83 & & 2,67 & 2,70 \\
Average past performance standards & 2,08 & $* *$ & 3,73 & 3,43 \\
Others & 1,25 & & 1,73 & 1,64 \\
\hline
\end{tabular}

Notes: ** Significant at 1 per cent. The means are calculated for all responses.

\subsection{Frequency in Reviewing Standards}

The highly competitive environment shortens the life cycles of the products. It can be assumed that there is an increase in the review frequency of the standards. According to the results described in Table 11, the responses are almost equally distributed among the options except for the "annually" response. Primary firms mostly (42\%) review the standards when the variances are no more tolerable. On the other hand, 44 percent of the primary firms reviewed the standards on a semi-annual basis. In Turkey, most of the companies increase salaries in January and July, which can be the reason to review the standards biannually. The review of the standards is not similar in the other three studies that are carried in three different countries (Drury et al., 1993; Marie et al., 2010; Sulaiman et al., 2005)."Annually" was the most widely selected option in the Malaysia and the UK surveys. The main difference arises in the frequency of the review. In Turkey, the review ratio is higher than it is in other countries. One reason might be the importance given to variance analysis is high. Equally, standards may require a frequent review due to the changing modern production conditions to reach the high quality requirement of the automotive industry.

Organizations adopt a philosophy of continuous improvement, an ongoing process that involves a continuous search in order to decrease costs, eliminate inefficiencies and improve the quality and performance of activities that increase customer satisfaction. It is claimed that standards are set in order to indicate the targets to be reached instead of creating a continuous improvement philosophy mindset within the firm. A continuous improvement philosophy may achieve consistency and usefulness of standard costing if variances are used to monitor the trend and the rate of change in performance. Such a corporate climate would enable standards to be regularly reviewed and tightened as improvements occur (Drury, 2009). Table 11 shows that the standards are frequently reviewed in the primary automotive industry.

Table 11. How frequently are standard costs formally reviewed?

\begin{tabular}{llllll}
\hline & \multicolumn{2}{l}{ Turkey } & & Malaysia & $\begin{array}{c}\text { UK } \\
(\%)\end{array}$ \\
\cline { 2 - 5 } & Primary Firms (\%) & Supplier Firms (\%) & Total (\%) & $(\%)$ & 16 \\
Monthly or quarterly & 33 & 13 & 16 & 22 & 14 \\
Semi-annually & 17 & 44 & 39 & 28 & 9 \\
Annually & 0 & 16 & 13 & 29 & 68 \\
Continuously & 8 & 16 & 15 & 16 & 6 \\
When the variances imply that the standards have changed & 42 & 11 & 16 & 6 & 3 \\
Total & 100 & 100 & 100 & 100 & 100 \\
\hline
\end{tabular}

Note: $\mathrm{n}=67$.

The MWU test indicated there were no significant differences between primary and supplier.

\subsection{Method Used to Determine if a Variance Should Be Investigated}

All the primary firms responded that they use a specific method for the question relating to the method used for analyzing important variances. $33 \%$ of the primary firms analyze variances exceeding an important monetary level, $42 \%$ used a determined ratio, and $25 \%$ analyzed by control charts or statistical methods. Primary firms do not rely on the determination of managerial judgment. The responses of the supplier firms indicated that 3 percent relied on managerial judgment, 38 percent relied on predetermined percentage level and 27 percent used control charts or other statistical methods. The results tend to agree with the study carried out in Malaysia (Sulaiman et al., 2005). In the study carried out in the UK (Drury et al., 1993), control charts and other statistical methods are not 
used to examine variances; rather, managerial judgment is used in a widespread manner. One possibility for the difference is that these methods were not frequently used in 1990s.

Table 12. Method used to determine if a particular variance should be investigated

\begin{tabular}{llllll}
\hline & Turkey & & Malaysia & UK \\
\cline { 2 - 4 } & Primary Firms (\%) & Supplier Firms (\%) & Total (\%) & $(\%)$ \\
\hline No formal method used (decision based on managerial judgment) & 0 & 4 & 3 & 47 & 75 \\
Where the variance exceeds a specific monetary amount & 33 & 31 & 31 & 63 & 41 \\
Where the variance exceeds a given percentage of standard & 42 & 38 & 39 & 66 & 36 \\
Statistical basis using control charts or other statistical models & 25 & 27 & 27 & 26 & 3 \\
\hline
\end{tabular}

Note: $\mathrm{n}=67$.

The MWU test showed no statistically significant differences between the primary and supplier firms for the investigation of a specific variance.

\subsection{Importance of Variances as an Aid to Control}

The last question investigates the significance of specific variances for management control (Tables 13 and 14). All of the 100 per cent responses show that while primary firms perceive many factors as important for control purposes, supplier firms perceived only material usage, price and labour efficiency as the most important factors.

The primary and supplier firms' responses indicate that the most important cost items to analyze variances are material price and material usage variances. Primary firms were 100\% relating to material price/usage, labour efficiency, overhead efficiency/ expenditures variances, and sale price/volume variances. Other than the main cost constituents such as material, labour, and overhead, primary firms attach a certain importance to variable management, variable marketing, research and development, and finance expenses. When the percentages are considered, supplier firms give $96 \%$ importance to material price, $91 \%$ importance to material usage, and $100 \%$ importance to labour efficiency variances. The other cost items such as labour wage rate, overhead, management, marketing, research and development, and finance expenses are not important for supplier firms. The comparison with the other international studies (Drury et al., 1993; Sulaiman et al., 2005; Marie et al., 2010) cannot be fulfilled for the management, marketing, research and development, and finance expenses (Note 2).

It is assumed that the share of the labour costs as a percentage of total cost decreased during time, especially in the automated manufacturing systems. Thus, some academicians argue that it may not be essential to investigate labour variances. However, this study shows that labour costs are still controlled by the management, and the variances are still important for analyzing. It can be concluded that the overhead costs that have a high share in the total manufacturing costs are closely monitored by the firms.

Table 13. How important each cost variance as an aid to control

\begin{tabular}{|c|c|c|c|c|c|}
\hline & \multicolumn{3}{|l|}{ Turkey } & \multirow{2}{*}{$\begin{array}{l}\text { Malaysia } \\
(\%)\end{array}$} & \multirow{2}{*}{$\begin{array}{l}\text { UK } \\
(\%)\end{array}$} \\
\hline & Primary Firms (\%) & Supplier Firms (\%) & Total $(\%)$ & & \\
\hline Material price & 100 & 96 & 97 & 93 & 69 \\
\hline Material usage & 100 & 91 & 93 & 90 & 66 \\
\hline Material mix & 0 & 0 & 0 & 50 & 35 \\
\hline Material yield & 0 & 15 & 12 & 56 & 52 \\
\hline Wage rate & 67 & 67 & 67 & 73 & 86 \\
\hline Labour efficiency & 100 & 100 & 100 & 74 & 65 \\
\hline Variable overhead efficiency & 100 & 62 & 69 & 68 & 32 \\
\hline Overhead expenditure & 100 & 71 & 76 & 72 & 69 \\
\hline Fixed overhead volume & 17 & 31 & 28 & 53 & 28 \\
\hline Fixed overhead volume efficiency & N/A & $\mathrm{N} / \mathrm{A}$ & $\mathrm{N} / \mathrm{A}$ & 49 & 18 \\
\hline Fixed overhead volume capacity & $\mathrm{N} / \mathrm{A}$ & $\mathrm{N} / \mathrm{A}$ & $\mathrm{N} / \mathrm{A}$ & 65 & 18 \\
\hline Variable management expenses & 92 & 36 & 46 & $\mathrm{~N} / \mathrm{A}$ & N/A \\
\hline Fixed management expenses & 17 & 31 & 28 & N/A & N/A \\
\hline Variable marketing expenses & 92 & 40 & 49 & $\mathrm{~N} / \mathrm{A}$ & N/A \\
\hline Fixed marketing expenses & 0 & 27 & 22 & $\mathrm{~N} / \mathrm{A}$ & $\mathrm{N} / \mathrm{A}$ \\
\hline Research and Development expenses & 75 & 27 & 36 & N/A & N/A \\
\hline Financial expenses & 67 & 24 & 31 & N/A & N/A \\
\hline Sales volume & 100 & 93 & 94 & 93 & 70 \\
\hline Sales price & 100 & 93 & 94 & 91 & 69 \\
\hline
\end{tabular}

Note: $\mathrm{n}=67$. 
In Table 14, the MWU test showed significant differences for several factors between primary and supplier firms. A possible explanation relating to material usage is that the primary firms produce by assembly so that the material usage variance might be low. On the other side, supplier firms manufacture specific products, and hence the material usage variance may have important fluctuations. For instance, an important negative variance may occur due to scrap. Other important differences arise in the fixed overhead volume, variable management expenses, variable marketing expenses, R\&D expenses, and financial expenses. Especially, the expense items are more important for primary firms compared to supplier firms. One possible answer is that primary firms can document, report and analyze these expense items. On the other hand, supplier firms may concentrate mostly on material and labour, and many expense items may be unavoidable.

Table 14. How important each cost variance as an aid to control (means)

\begin{tabular}{|c|c|c|c|c|c|c|}
\hline & \multicolumn{4}{|l|}{ Turkey } & \multirow[t]{2}{*}{ Malaysia } & \multirow[t]{2}{*}{ UK } \\
\hline & Primary Firms & M-W test & Supplier Firms & Total & & \\
\hline Material price & 4,58 & $*$ & 4,25 & 4,31 & 4,54 & 4,00 \\
\hline Material usage & 4,33 & $* *$ & 4,73 & 4,66 & 4,31 & 3,86 \\
\hline Material mix & 3,00 & & 2,85 & 2,88 & 3,40 & 2,77 \\
\hline Material yield & 3,00 & & 3,00 & 3,00 & 3,54 & 3,33 \\
\hline Wage rate & 3,75 & & 3,64 & 3,66 & 3,88 & 3,10 \\
\hline Labour efficiency & 4,50 & & 4,47 & 4,48 & 4,12 & 3,74 \\
\hline Variable overhead efficiency & 4,17 & & 3,75 & 3,82 & 3,76 & 2,79 \\
\hline Overhead expenditure & 4,17 & & 3,91 & 3,96 & 3,95 & 3,91 \\
\hline Fixed overhead volume & 2,33 & $* *$ & 3,36 & 3,18 & 3,47 & 2,71 \\
\hline Fixed overhead volume efficiency & N/A & & N/A & N/A & 3,36 & 2,24 \\
\hline Fixed overhead volume capacity & N/A & & N/A & N/A & 3,65 & 2,31 \\
\hline Variable management expenses & 4,00 & $* *$ & 3,00 & 3,18 & N/A & $\mathrm{N} / \mathrm{A}$ \\
\hline Fixed management expenses & 2,67 & & 2,96 & 2,91 & N/A & N/A \\
\hline Variable marketing expenses & 4,00 & $* *$ & 2,98 & 3,16 & N/A & $\mathrm{N} / \mathrm{A}$ \\
\hline Fixed marketing expenses & 2,08 & & 2,85 & 2,72 & N/A & $\mathrm{N} / \mathrm{A}$ \\
\hline Research and Development expenses & 3,67 & $* *$ & 2,84 & 2,99 & N/A & $\mathrm{N} / \mathrm{A}$ \\
\hline Financial expenses & 3,67 & $* *$ & 2,80 & 2,96 & N/A & $\mathrm{N} / \mathrm{A}$ \\
\hline Sales volume & 4,33 & & 4,36 & 4,36 & 4,49 & 3,93 \\
\hline Sales price & 4,50 & $*$ & 4,07 & 4,15 & 4,41 & 3,93 \\
\hline
\end{tabular}

Notes: * Significant at 5 per cent, $* *$ Significant at 1 per cent. The means are calculated for all responses.

Fixed overhead volume efficiency and capacity are not calculated and reported in the Turkish Standard Chart of Accounts. On the other hand, some expense items are included in the questionnaire for which the corresponding Malaysia and the UK studies did not investigate. The MWU test has also revealed a significant difference in "sales prices" between primary and supplier firms. As the Turkish automotive industry is the largest export industry, the sales prices are affected by the change of the local currency against hard currencies. Therefore, currency fluctuations may cause variances in sales price that must be followed closely and managed by primary firms. Supplier firms' sales tend to be in local currency and most of the time they cannot act independently to set the sales prices. They have long-term contracts with the primary firms which have an influential effect on setting their purchasing price. Therefore, the importance of this variance is significantly emphasized more by the primary firms than supplier firms for management control.

\section{Conclusion}

It is concluded that the standard costing is still used in the automotive industry in Turkey, despite a general belief by some academicians who argue that the standard costing is out of date. The twelve primary firms among the thirteen who responded to the questionnaire have reported that they use standard costing. 280 supplier firms which operate in the organized industrial zones are selected, and $71 \%$ of the responded firms use standard costing. The majority of non-users are local small firms. In total, in the Turkish automotive industry, the usage of standard costing is $74 \%$ among all the firms which have responded to the survey. This result is similar to the ones in the UK (Drury et al., 1993), Malaysia (Sulaiman et al., 2005), and Dubai (Marie et al., 2010) that studied the manufacturing sector.

The main purpose of the usage of cost accounting is $100 \%$ cost control and performance evaluation. The use of standard costing for inventory valuation, computing product cost for decision making, and as an aid to budgeting 
were given a $100 \%$ importance rating for the firms in primary industry, while the costing inventories and computing product cost for decision making were more than $90 \%$ of importance for supplier firms. A statistical difference for "as an aid to budgeting" signals that primary firms employ the budgeting function to a statistically greater degree than supplier firms do.

All of the primary firms set labour and material standards based on design and engineering studies. $64 \%$ of supplier firms set the standards by using historical averages. Supplier firms also utilize observations based on trial runs, and work study techniques. It is not appropriate to compare the studies carried out in the UK (Drury et al., 1993) and Malaysia (Sulaiman et al., 2005) as the sample of those studies comprise all of the manufacturing industry. In the work carried out by Marie et al. (2010), the automotive industry was not included in the data.

The primary and supplier firms indicated that the material usage and material price variances were the crucial cost items in the analysis of the variances. Primary firms responded by $100 \%$ that material price/usage, labour efficiency, overhead and sale price/quantity variances are the most important variances. Other than the main cost constituents such as material, labour and overhead, primary firms attach a certain importance to variable management, variable marketing, research and development, and finance expenses. When the percentages are considered, supplier firms gave $96 \%$ importance to material price, $91 \%$ importance to material usage, and $100 \%$ importance to labour efficiency variances. The other cost items such as labour wage rate, overhead, management, marketing, research and development, and finance expenses are not important for supplier firms. The comparison of this study to the other international studies (Drury et al., 1993; Sulaiman et al., 2005; Marie et al., 2010) cannot be fulfilled for the management, marketing, research and development, and finance expenses. In the Turkish uniform accounting system, fixed overhead variances are not calculated by different types so the results could not be compared to other foreign studies. In terms of the main production costs (material, labour, and overhead costs), material cost variances in the Turkish automotive industry are at a similar percentage level with those of studies conducted in other countries; the importance in terms of percentage for labour and especially for overhead costs are greater than the results of those other studies. It is assumed that the labour costs as a percentage of total cost decreased during time, especially in the automated manufacturing systems. Therefore, some academicians argue that it is not essential to investigate labour variances. However, this study shows that labour costs are still controlled by the management, and the variances are still important for analysis. It can be concluded that the overhead costs that have a high share in the total manufacturing costs are closely monitored by the firms.

In conclusion, this study has examined the current usage of standard costing in today's modern production to assess the claims of the relevance of this method. This study indicates that the standard costing continues to be widely used in the Turkish automotive industry. Drury (2009) explains that the firms still benefit from the usage of standard costing not only for cost control and performance appraisal analysis but also the method supply cost information for different aims.

The findings are subject to some limitations. The study does not include all the industries in Turkey but focuses on the automotive industry where standard costing can be easily applied. Therefore, the results cannot be generalized for the whole manufacturing industry in Turkey. Other similar studies are needed in order to understand the reasons and ways of the usage of managerial accounting tools in manufacturing firms in Turkey. The ratio of responses is very high in the main industry. Twelve out of thirteen firms have responded to the questionnaire. The number of the supplier firms is high so the sample has been narrowed to 300 firms. The supplier firms' response rate is $26 \%$, which can be considered a low percentage. However, SMEs have fewer tendencies to share internal information about their firm. Therefore, $26 \%$ is considered to be an acceptable response rate. The questionnaire was sent to the accounting manager or his assistant. It may have also been appropriate to obtain the responses of the users of the accounting information (e.g. the production managers).

In spite of these constraints, the outcomes of this study draw attention the relevance and usage of standard costing in the Turkish automotive industry. Future research should be applied to other industries in order to ascertain whether there are differences and similarities among those industries.

\section{References}

Ahn, T. S., \& Lee, C. H. (1994). Effect of manufacturing environment changes on cost management practices. Korean Accounting Journal, 2(1), 113-130.

Automotive Manufacturers Association (OtomotivSanayiiDerneği) AMA. (2011). Automotive Industry Evaluation Report. Retrieved from http://www.taysad.org.tr/www/tr/default.asp? $\mathrm{x}=$ sektorel\&s=3

Bromwich, M., \& Wang, G. (1991). Management accounting in China: a current evaluation. The International Journal of Accounting, 26(1), 51-65. 
Büyükmirza, K. (2003). MaliyetveYönetimMuhasebesi (Cost and Management Accounting). Ankara: GaziKitabevi.

Cornick, M., Cooper, W., \& Wilson, S. (1985). A survey of budget-related planning and control policies and procedures. Journal of Accounting Education, 3, 61-78. http://dx.doi.org/10.1016/0748-5751(85)90007-7

Diga, J. (1997). Accounting in the Philippines. In Baydoun, N., Nishimura, A., \& Willet, R. (Eds.), Accounting in the Asia, Pacific Region. Singapore: John Wiley Sons (Asia) Pte. Ltd.

Drury, C. (1999). Standard costing: a technique at variance with modern management? Management Accounting, $77(10), 56-58$.

Drury, C. (2009). Management Accounting for Business (4th ed.). Cengage Learning. U.K. Learning Notes. Retrieved February 12, 2013 from http://www.drury-online.com/mab4/students/learningnotes/ln11.2.pdf

Drury, C., Braund, S., \& Osborne, P. (1993). A Survey of Management Accounting Practices in U.K. Manufacturing Companies. Chartered Association of Certified Accountants, London, England.

Dugdale, D., Jones, C., \& Green, S. (2006). Contemporary Management Accounting Practices in UK Manufacturing. Oxford: CIMA Publishing.

Ferrara, W. (1995). Cost and management accounting: the 21st century paradigm. Management Accounting, 36, 30-34.

Fleischman, R. K., \& Tyson, T. N. (1998). The evolution of standard costing in the U.K. and U.S.: from decision making to control. Abacus, 31(1), 92-119. http://dx.doi.org/10.1111/1467-6281.00024

Garg, A., Ghosh, D., Hudick, J., \& Nowacki, C. (2003). Roles and practices in management accounting today. Strategic Finance, 85(1), 30-35.

Garrison, R. H. (1998). Managerial Accounting. Boston: BPI, IRWIN.

Ghosh, B. C., \& Chan, Y. K. (1996). Management Accounting Practices in Singapore: The State of The Art. (Unpublished manuscript). Singapore: Nanyang Business School.

Ghosh, B. C., Chung, L. H., \& Wan, C. Y. (1987). Management Accounting in Singapore. Management Accounting, December, 28-30.

Guilding, C., Lamminmaki, D., \& Drury, C. (1998). Budgeting and standard costing practices in New Zealand and the United Kingdom. The International Journal of Accounting, 33(5), 569-588. http://dx.doi.org/10.1016/S0020-7063(98)90013-9

Gupta, K. M., \& Gunasekaran, A. (2004). Costing in new enterprise environment: a challenge for managerial accounting researchers and practitioners. Managerial Auditing Journal, 20(4), 337-353. http://dx.doi.org/10.1108/02686900510592034

Hansen, D. R., \& Mowen, M. M. (2002). Management Accounting (5th ed.). South Western College Publishing, International Thomson Publishing, Cincinatti, $\mathrm{OH}$.

Hilton, R. W. (2001). Managerial Accounting: Creating Value in a Dynamic Business Environment (5th ed.). New York, NY: McGraw-Hill Irwin.

Horngren, C., Foster, G., \& Datar, S. M. (2008). Cost Accounting: A Managerial Emphasis (13th ed.). NY: Prentice Hall.

Joshi, P. L. (2001). The international diffusion of new management accounting practices: the case of India. Journal of International Accounting, Auditing and Taxation, 10(1), 85-109. http://dx.doi.org/10.1016/S1061-9518(01)00037-4

Kaplan, R. S., \& Johnson, H. T. (1987). Relevance Lost: The Rise and Fall of Management Accounting. Boston: Harward Business School Press.

Kaygusuz, S. (2006a). Activity-based overhead variance analysis. The Journal of Accounting and Finance, 30, 152-162.

Kaygusuz, S. (2006b). YenilikçiYönetimMuhasebesi (Modern Management Accounting). Bursa: Alfa AktüelYayınları.

Küçüksavaş, N. (2006). YönetimAçısındanMaliyetMuhasebesi (Administrative Cost Accounting). Istanbul: KareYayınları.

Lucas, M. (1997). Standard costing and its role in today's manufacturing environment. Management Accounting, 
75(4), 32-34.

Lyall, D., \& Graham, C. (1993). Managers' attitudes to cost information. Management Decision, 31(8), 41-45. http://dx.doi.org/10.1108/00251749310047142

Marie, A., Cheffi, W., Louis, R. J., \& Rao, A. (2010). Is standard costing still relevant? Evidence from Dubai. Management Accounting Quarterly, 11(2), 1-10.

Monden, Y., \& Lee, J. (1993). How a Japanese auto maker reduces costs. Management Accounting, 75(2), 22-26.

Murshed, A. J. M. H. (1997). Accounting in Brunei Darussalam. In Baydoun, N., Nishimura, A., \& Willett, R. (Eds.), Accounting in the Asia, Pacific Region. Singapore: John Wiley Sons (Asia) Pte. Ltd.

OrganisationInternationale des Constructeursd'Automobiles OICA. (2011). Retrieved September 10, 2012 from http://oica.net/category/ production-statistics/

Puxty, T., \& Lyall, D. (1990). Cost control: the manager's perspective. Management Accounting, 68(11), 46-47.

Republic of Turkey Ministry of Economy RTME. (2012). Automotive Primary AndSuplier Industry. Retrieved August 15, 2012 from http://www.ibp.gov.tr/pg/sektorpdf/sanayi/otoyansanayi_2012.pdf

Scarborough, P., Nanni, A. Jr., \& Sakurai, M. (1991). Japanese management accounting practices and the effects of assembly and process automation. Management Accounting Research, 2(1), 27-46. http://dx.doi.org/10.1016/S1044-5005(91)70025-5

Sulaiman, M., Ahmad, N. N., \& Alwi, N. M. (2005). Is standard costing obsolete? Empirical evidence from Malaysia. Managerial Auditing Journal, 20(2), 109-124. http://dx.doi.org/10.1108/02686900510574539

Tho, L. M., Md. Isa, C. R., \& Ng, K. T. (1998). Manufacturing environment, cost structures and management accounting practices: some Malaysian evidence. AkauntanNasional, 3-12.

Tsai, W. (1995). An investigative study of management accounting education and practice in Taiwan. (Unpublished Thesis). Report to National Science Council, Taiwan.

Williamson, D. (1996). Cost and Management Accounting. UK: Prentice Hall.

\section{Notes}

Note 1. In addition to many advantages such as being cost-effective and enabling the collection of a reasonable and representative sample which this method provides, it might also be the only way to collect data which are not disclosed to the public.

Note 2. In the Turkish uniform accounting system, fixed overhead variances are not calculated by different types so the results could not be compared to other foreign studies. In terms of the main production costs (material, labour, and overhead costs), material cost variances in the Turkish automotive industry are at a similar percentage level with those of other studies conducted in other countries. The importance in terms of percentage of labour and, especially, of overhead costs is greater than the results of those in other studies.

\section{Copyrights}

Copyright for this article is retained by the author(s), with first publication rights granted to the journal.

This is an open-access article distributed under the terms and conditions of the Creative Commons Attribution license (http://creativecommons.org/licenses/by/3.0/). 